Article

\title{
Innovating Rural Tourism Targeting Poverty Alleviation through a Multi-Industries Integration Network: the Case of Zhuanshui Village, Anhui Province, China
}

\author{
Nanping Feng ${ }^{1,2, *}$, Fenfen Wei ${ }^{1}{ }^{(\mathbb{D}}$, Kevin H. Zhang ${ }^{3}$ and Dongxiao Gu ${ }^{1,2}$ \\ 1 School of Management, Hefei University of Technology, Hefei 230009, China; \\ weifenfen@mail.hfut.edu.cn (F.W.); gudongxiao@hfut.edu.cn (D.G.) \\ 2 Key Laboratory of Process Optimization and Intelligent Decision-making, Hefei University of Technology, \\ Ministry of Education, Hefei 230009, China \\ 3 Department of Economics, Illinois State University, Normal, IL 61790-4200, USA; khzhang@ilstu.edu \\ * Correspondence: fengnp@hfut.edu.cn; Tel.: +86-551-62901942
}

Received: 25 May 2018; Accepted: 21 June 2018; Published: 25 June 2018

check for updates

\begin{abstract}
For an impoverished area to employ rural tourism (RT) as an avenue of poverty alleviation, there are two main challenges: building competitiveness with a very limited endowed resource base, and targeting the poor who generally lack financial capital or key capabilities as the main beneficiaries. With a case of Zhuanshui in China, an impoverished village without prominent tourism resource endowment, this paper has shown that the two challenges can be met through an innovation to construct a multi-industries integration network. This paper explores the development of the network, examines its characteristics, and analyzes its operation mechanisms. Results indicate that (1) the common objective of poverty alleviation and the same fundamental resource, combine RT and its extension industries tightly into an integration network; (2) sufficient evidence has been found for the embeddedness, endogeneity and empowerment of the network, but for empowerment, the poor's participation is just the first stage to make appropriate decisions about the development due to their inadequate capabilities; and (3) vision developing, demonstration driving and centralized decentralization governance are three vital operational mechanisms to encourage the participation and collaboration of stakeholders. We also discussed the possible challenges for sustainability, being replicability of established competitive advantages, temporality of the major leader, and potential environmental degradation.
\end{abstract}

Keywords: rural tourism; poverty alleviation; integrated network; operation mechanisms; network characteristics; sustainability

\section{Introduction}

Tourism has long been exalted as a powerful weapon to attack poverty, and typical evidence is that the United Nations World Tourism Organization (UNWTO) launched the ST-EP programme (Sustainable Tourism for Eliminating Poverty) as a global action framework to harness tourism to alleviate poverty [1,2]. Accordingly, rural tourism (RT) has been taken as an effective tool for poverty alleviation in less-developed rural areas [3,4]. For example, in China, according to data from the China National Tourism Administration, through the promotion of RT, over 10 million Chinese poor residents in rural areas have thrown off poverty from 2010 to 2015, and a target amount of 12 million was expected from 2016 to 2020. In order to achieve the goal, China put forward 'rural tourism targeting anti-poverty' (RTTAP) to exert a more direct and phenomenal impact of tourism on poverty 
alleviation. The new philosophy set poverty alleviation as the central or one of the central objectives, emphasizing the voices and needs of the local poor in RT development.

Although the new philosophy is anchored in the hope of greatly enhancing the poor's net benefits from RT and promises a bright future for poverty alleviation, its implementation faces two main challenges. One challenge is how to develop RT in rural areas without prominent tourism resource endowment (mainly referring to natural or cultural landscape). In past years, RT has been developed rapidly in rural areas with prominent tourism resource endowments because it is easy for them to attract tourists. For example, Xidi and Hongcun, located in the southern Anhui Province of China, have become two of China's most famous and favorite tourist destinations, because they are typical representations of the Hui Culture- one of the most influential cultures during the evening period of feudal China, from 17th to 19th century [5]. Nevertheless, many impoverished areas do not have abundant tourism resource endowment to attract tourists. How can these impoverished destinations build competitiveness? Moreover, research has demonstrated that the poor usually are not the main beneficiaries in the process of tourism development $[2,6]$ because they generally lack financial capital or key capabilities [1]. Thus the second challenge is how can RT focus on the real issue-targeting the poor as the main beneficiaries and helping them out of poverty?

This paper aims at the two main challenges through a case from China. Unlike many cases with characterized natural beauty [7] or influential cultures [5] in literature, our case, Zhuanshui Village, initially owned almost no special rural scenery or surviving tangible cultural relics. But it innovated RTTAP through multiple industries integration and attracted tourists consistently; $93 \%$ of the poor have successfully escaped poverty in just four years. How did it develop the multi-industries integration network? What are the characteristics and operation mechanisms of the integrated network? Exploring these issues of the case village is meaningful to enlighten other similar impoverished areas to meet the two challenges and develop RTTAP.

Moreover, some scholars pointed out that although there is a considerable amount of literature on tourism management, relatively little is suitable to the needs of those in impoverished destinations, and for a given impoverished area, the elimination of poverty inherently requires a combination of tourism with other poverty-alleviation approaches [1]. Thus, the paper is also a response to these appeals.

\section{Literature Review}

\subsection{Tourism and Poverty Alleviation}

The Pro-Poor Tourism Partnership in the United Kingdom in the late 1990s has been recognized to be the earliest research initiative to tap the potential of tourism in poverty alleviation and responsible for most of the early related research [8,9]. Inspired by the Pro-Poor Tourism Partnership, many tourism-based development projects were launched around the world, for example by the United Nations and China. However, despite the worldwide mushrooming interest in tourism-based poverty alleviation, poverty alleviation and relevant issues had been largely neglected by the tourism academics at that time [1]. To address these deficiencies, Zhao and Ritchie [1] presented an integrative 'anti-poverty tourism' (APT) research framework, consisting of four levels-'poverty alleviation', 'determinants', 'APT themes' and 'stakeholders'. The later research mainly focused on two topics: the impacts of tourism on poverty alleviation and the contributions of micro- and small- tourism enterprises to poverty alleviation.

The impacts of tourism on poverty alleviation. Blake et al. [2] examined the issue of how tourism affects poverty and developed a framework for analyzing the channels through which tourism influences different households. Snyman [10] assessed various impacts of ecotourism employment on surrounding rural communities at study sites in Botswana, Malawi and Namibia. Mitchell [11] examined the impacts of tourism on local communities and justified a value chain approach to assessing the impact of tourism on low-income households in developing countries. 
The contributions of micro- and small- tourism enterprises to poverty alleviation. Many scholars of pro-poor and responsible tourism argued that small tourism businesses can contribute to poverty alleviation [12,13], and some policy-makers, such as in South African townships, also supported small tourism businesses for alleviating poverty [14]. UNWTO also emphasized the development of micro-, small- and medium-sized tourism enterprises as a valuable means of alleviating poverty, and community-based enterprises (CBEs) are preferred in Kenya [15]. Scheyvens and Russell [16] compared the contributions of small- and large-scale tourism enterprises to poverty alleviation using the multidimensional view of poverty modelled on Zhao and Ritchie's integrative research framework. However, by conducting an empirical study, Koens and Thomas [14] found that for micro-enterprises, their narrow social networks, the imbalances of power between them and intermediaries such as travel agencies and tour operators, and complex family and ethnic ties, all represent barriers that prevent them from developing their businesses and sharing in the material gains available through tourism.

There are some other fragmented topics in the literature, for example, the relationships between tourism development, gender and poverty reduction [17], tourism foreign direct investment (FDI) and poverty alleviation [18], some specific challenge for pro-poor tourism [19], drivers and beliefs of an aid agency seeking to alleviate poverty via tourism development [20], and the perceptions and experiences of poor people regarding tourism as a means of poverty alleviation [6], and so on.

\subsection{Rural Tourism}

Although there are numerous concepts of rural tourism [21-23], its basic aspects include: taking place in rural areas; depending on the rural scenery and human activities as key tourist attractions; aiming to contribute to the development of rural areas; and being sustainable [3].

The development of rural tourism may have different models. According to the tourist attractions, there are pastoral agriculture tourism, folk custom tourism, village and township tourism, leisure and vacation tourism, and agricultural knowledge tourism [3]. According to operation mode, there are household-run small business, individual farmstead, farmer family plus farmer family, corporation plus farmers, corporation plus community plus farmers, government plus corporation plus farmers [24].

Networking has potential as a structure to enhance competitiveness and innovation of a rural tourism destination $[25,26]$. It may be a means of overcoming lack of resources faced by small firms when it comes to innovation [27], contributing towards the creation of a cohesive destination [25]. The interactions of networks related to rural tourism can be along the marketing information dimension, administrative resources dimension, human resources dimension, or training and financial resources dimension [7].The stakeholders of the networks cooperate and form a dynamic social relationships in order to achieve tourism-related goals [28]. Social capital can help to build rural tourism micro firm network [29] and affect community conflict management for community residents in rural tourism villages [30]. High social capital assists in increasing the effectiveness of rural tourism development [30,31]. In particular, the elements of social capital, such as trust [29,32], the specific manner in which Chinese indigenous residents dwell in their place-guanxi—were examined in Chinese rural tourism development [33].

The roles of the main stakeholders of rural tourism, including individual entrepreneurs, community and government, also have garnered interest from scholars. Komppula [34] argued that without innovative, committed, and risk-taking entrepreneurs, no destination will flourish. Community participation in rural tourism is helpful for desirable interrelations among tourism stakeholders $[5,35]$. The government also has a crucial role to be facilitator of the entrepreneurial environment $[34,36]$, the mediator in establishing trust relationships with the rural service providers [26,37], and policy maker of rural tourism [38,39].

As for the methodologies, most of the research in tourism-based poverty alleviation and rural tourism domain used a case study method $[4,5,25,29,31,33-35,38,40,41]$, and many cases come from China $[4,5,33,35,38,40,41]$.

From the literature, it also can be concluded that, although related research is being constantly enriched, little enlightenment for the practical challenges those impoverished destinations with 
resource constraints are facing can be found. How can the destinations build competitiveness and target the poor as the main beneficiaries to throw off poverty? The mismatch between research and practice obviously is worthy of greater research efforts and an urgent need for challenges' solutions should be highlighted.

\section{Research Methodology}

\subsection{Research Context}

Zhuanshui Village in Anhui Province, which is $70 \mathrm{~km}$ away from the capital City Hefei, has become quite a famous rural tourism destination in Anhui and the surrounding provinces during the last four years. Before 2014, Zhuanshui Village was a typical poor village without properties, resources or leading industries. There were a total of 586 households and 2066 residents in the village, but the archived poor were up to 128 households, 366 residents. An archived poor household means that the per capita net income in the family is under the national poverty identification standard and thus is included in the national poverty alleviation management system.

However, 2014 was a turning point. Zhuanshui Village began to shift its livelihood direction to rural tourism based on Chinese toon, a species of Toona that is native and deciduous. The bark is brown, smooth on young trees, but becomes scaly to shaggy on old trees. The individual leaf is 9-15 $\mathrm{cm}$ long and $2.5-4 \mathrm{~cm}$ broad, with an entire or weakly serrated margin. Chinese toon is a preferred tree for landscaping. Its leaves have rich nutrients including protein, calcium, vitamin C, iron and B vitamins. The leaves also have a therapeutic effect on several cancer cells and may improve learning and memory. Thus, the tender leaves, with a floral yet onion-like flavor, are extensively used as a vegetable in China. For ordinary cultivation, the first harvest is around 20 April, and every 15-20 days after that the leaves can be harvested once more, with 2-3 times in total. For greenhouse cultivation, the first harvest can be as early as January, with a harvest interval of 7-10 days and 4-5 times in total. In 2013, there were only dozens of $\mathrm{mu}(1 \mathrm{mu}=0.0667$ hectares $)$ of Chinese toon sparsely planted in the whole village, while at present the planting area is more than $3000 \mathrm{mu}$ (about 200 hectares). Chinese toon sightseeing and picking, toon dishes in Nongjiale (a popular rural tourism product in China, with the salient characteristic of providing "leisure farm" for tourists and vacationers to experience and enjoy the joyfulness of rural life [24]), have become unique tourist attractions. Moreover, in order to further enhance and stabilize the poor's income, the RT industry chain has been extended to planting, breeding and processing. All the industries are based on Chinese toon and integrated to form a multiple industries network. The effect of the integration for poverty alleviation is notable. By the end of 2017, 349 out of the 366 poor residents had successfully escaped poverty.

\subsection{Methodology and Data Collection}

We explore solutions for the two challenges by conducting a case study. This is a method that can deeply describe and analyze a certain specific phenomenon based on abundant qualitative data [42], and most likely addresses "how" research questions [43]. It has been widely used in rural tourism research $[4,5,25,29,31,33-38,40,41]$.

There are three type of data sources in our study, including semi-structured interviews, archival data and media reports. Different data can form a triangle test $[42,44]$, ensuring the accuracy of the information. Before interviews, we referred to the related websites to get media reports about the village, which could help us to get a preliminary understanding. Then, we interviewed five different types of stakeholders to collect the related data: (1) the leader presiding RTTAP, (2) members of villagers' committee, (3) personal small business operators, (4) local residents who have thrown off poverty, and (5) tourists. Table 1 shows the list of interviewees. The leader was temporarily selected and appointed by 'the Agency and Staffing Committee Office of Anhui province' (ASCOAH) to preside over RTTAP. The villagers' committee was a five-person group and we interviewed the oldest and the youngest for potentially different perspectives. The four personal small business operators interviewed 
were selected from four different industries of the integration network. The local residents and tourists were randomly selected.

The interviews were carried out during two periods: a seven-day period in July 2017 and a five-day period in September 2017. A semi-structured format with both open and closed questions was adopted for all the interviews. The interviews lasted more than $1 \mathrm{~h}$ and were tape-recorded and transcribed for content analysis. The interview focuses of different stakeholders are presented as follows.

(1) The temporary leader. The interview focused on the whole development process of RTTAP, including idea generation, strategic decision making, initiation, expansion, construction of the network, etc.

(2) The members of villagers' committee. The interviews began by asking them to introduce the village's history briefly, and the status quo in detail. Then based on the information from the leader, we traced the important events identified in the leader interview and asked them to give a supplement, if there was any.

(3) The personal small business operators. There were four different industries in the network and, thus, we conducted four interviews in total. Each operator introduced his business, the reason he initiated it, and the activities of the poor in the business.

(4) The local residents. We randomly selected three local residents who have escaped poverty to conduct the interviews. The interviews focused on brief introduction and main income avenues of their households, as well as their participation and perception about the RTTAP work.

(5) The tourists. We randomly selected two tourists to conduct the interviews. The interviews focused on the channels they know in the village and the things they spend money on when they travel to the village.

Table 1. List of interviewees of the study.

\begin{tabular}{ccc}
\hline Type of Stakeholders & Interviewee No. & Description \\
\hline Temporary anti-poverty leader & Z01 & $\begin{array}{c}\text { Presider of 'rural tourism targeting } \\
\text { anti-poverty' (RTTAP) }\end{array}$ \\
\hline \multirow{2}{*}{ Members of villagers' committee } & Z02 & Leaders at village level \\
\hline \multirow{2}{*}{ Personal business operators } & Z03 & Operator of Nongjiale \\
& Z04 & Operator of eco-development enterprise \\
& Z06 & Operator of planting enterprise \\
Local residents & Operator of processing enterprise \\
\hline \multirow{2}{*}{ Tourists } & Z08 & Residents who have escaped poverty \\
& Z10 & during 2014-2017 \\
\hline & Z11 & Tourists in the village \\
\hline
\end{tabular}

\section{Findings and Discussion}

\subsection{Developing a Multi-Industries Integration Network for 'Rural Tourism Targeting Anti-Poverty' (RTTAP)}

Since RT was deemed as an effective approach for poverty alleviation, the temporary anti-poverty leader was appointed to develop RTTAP in the village. However, the village did not have any attractive scenic spots. How to innovate RT development to attract tourists and increase the poor's income thus became a puzzle. After a thorough investigation and survey, the leader thought that the RT development of the village should be based on Chinese toon. The reasons are as follows. Firstly, in spite of sparse planting, Chinese toon is a kind of traditional tree in the village, and it is also preferred for landscaping. Secondly, the characteristics of Chinese toon planting, including low cost, no strict skills 
requirement, and being seasonable thus just needing low labor intensity, make it very feasible and suitable for the village. As most of the young have left as migrant workers, those residents who remain are almost all old people and children who cannot afford much money or do work with strict skills or intense labor requirements. Thirdly, the tender leaf of Chinese toon is a kind of edible wild herb with rich nutrients and a therapeutic effect, meeting the needs of modern people for healthy food. Therefore, in 2014, the residents were called upon to plant Chinese toon and an integrated multiple industries network was gradually established during the development (Figure 1).

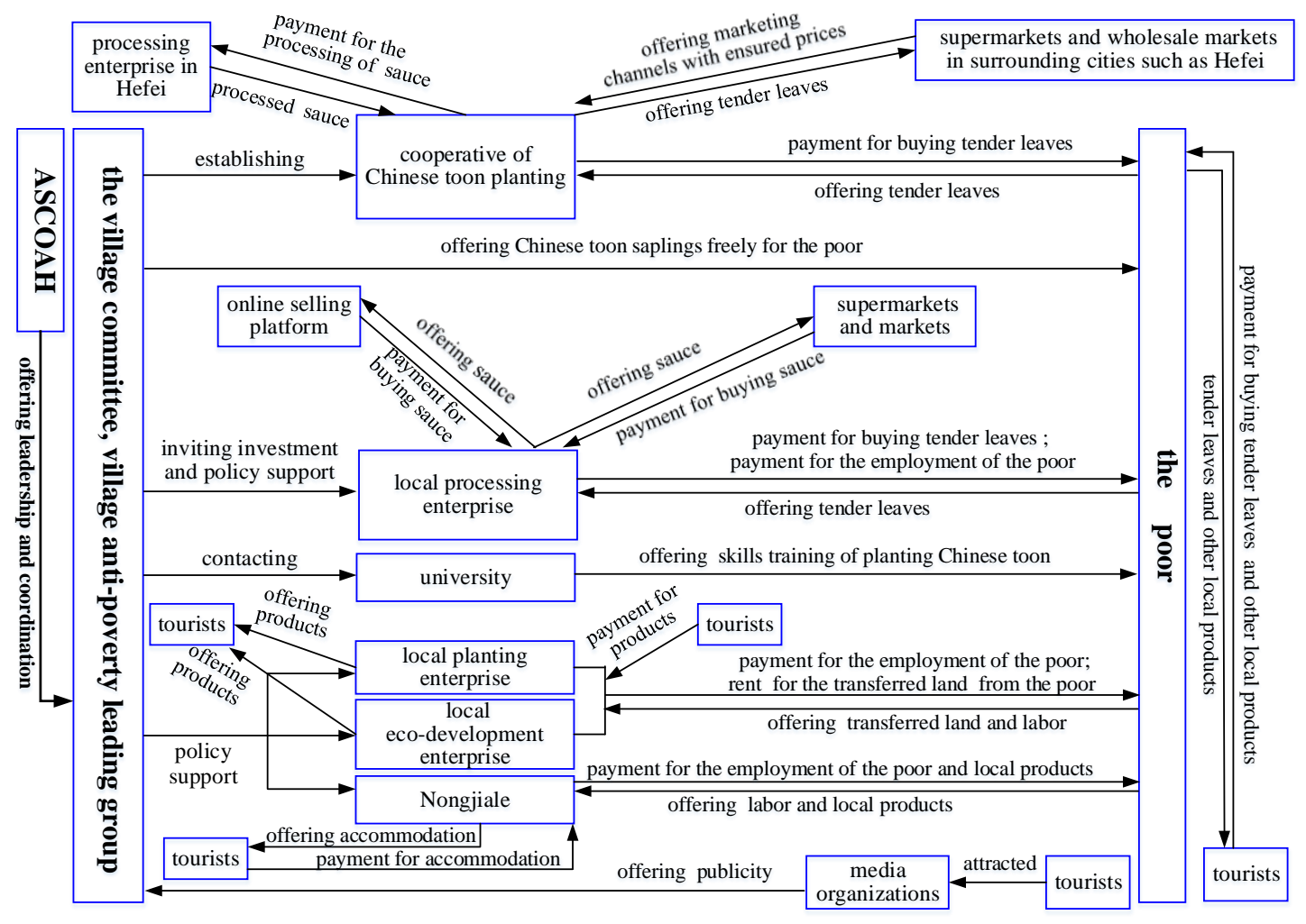

Figure 1. The multi-industries integration network for RTTAP.

The concept of a multi-industries integration network has two meanings. Firstly, the development of RT is mainly sustained by a social network that explicitly links different stakeholders together with social, cultural, economic and environmental resources. Secondly, in order to offer more income avenues for the poor and better achieve poverty alleviation, the business operators involved are not merely from tourism but from multiple industries with inner linkages. To be specific, besides tourism there are the planting industry, breeding industry and processing industry in the network. In other words, the integrated network sets poverty alleviation as the central objective, links different stakeholders and combines multiple industries to jointly promote the objective realization. Notably, although RT is not the mere development option, it is the core and the other industries are in fact its extensions.

\subsubsection{The Extension to Planting and Breeding Industries}

The prerequisite for Chinese toon sightseeing and picking tourism is that the planting should be on a certain scale. However, there was only a sparse distribution of Chinese toon in 2013. Therefore, in order to transform the village into a destination, the first thing was to increase the Chinese toon planting area.

In the past, because of inconvenient transportation and low business skills, the only channel for the poor to sell the tender leaves was through few vendors who came to the village for a concentric 
acquisition. Thus even if with a good harvest, the total income was not high because the vendors always offered a rather low price. This directly resulted in almost no motivation in planting and a sparse distribution.

"We of course are willing to plant Chinese toon if we need not worry about how to sell the tender leaves and at the same time sell at a suitable price."

(Interviewee Z08)

To ensure the price and the total income, a cooperative of Chinese toon planting was established by the villagers' committee in 2014. The main obligation of the cooperative was to build marketing channels. It collected the tender leaves from the local residents and then negotiated a price with the supermarkets and wholesale markets in surrounding cities such as Hefei. The cooperative always have a much stronger bargaining power than individuals because of a larger supply amount.

"In order to arouse the enthusiasm of residents to plant Chinese toon, we must ensure their tender leaves could be sold out and sold at a satisfactory price. The professional cooperative can package all the planters' tender leaves together and bargain with the purchasers"

(Interviewee Z01)

"Through negotiations with the wholesale markets and supermarkets, we can sell the tender leaves to them at an ensured price of no less than 40 Yuan in RMB per kilo, and the duration of offering tender leaves is always more than 10 days. This effectively guarantees the total income of the planters and the annual incomes of some leading planters can reach more than 40,000 Yuan." (1 Yuan $\approx 0.1563$ dollars, at the current exchange rate).

(Interviewee Z02)

Moreover, the villagers' committee further initiated a declaration process of the local tender leaves to be an organic agricultural product in 2015 and the declaration was approved by the Ministry of Agriculture in 2016. Accordingly, the price of the product was greatly raised once more.

"Now we can sell the tender leaves to the cooperative at a high price. Planting Chinese toon is also very simple. I can do the work even I am 75 years old."

(Interviewee Z08)

Because of the ensured marketing channels and the attractive price, most residents began to plant Chinese toon. In particular, a local elite was eager to tap the potential opportunity and raised funds to establish a planting enterprise. He transferred land from local residents with rents and launched a large-scale planting with greenhouse technology. Through the control of temperature and humidity in the greenhouse, the tender leaves can be sold as early as in January, while the ordinary time to market is April.

Illuminated by the idea, another local elite established an eco-agricultural development enterprise to breed livestock and poultry such as pigs and chook. Interestingly and uniquely, the main feed of the livestock and poultry are the unsaleable old leaves of Chinese toon. This also becomes the selling points and the products are very popular with consumers although at a rather high price.

Except for the rents of transferred land, the two enterprises also paid for the employment of the poor.

\subsubsection{The Extension to a Processing Industry}

With the sharply increasing planting area, the yield of the tender leaves greatly exceeded the order quantity of the supermarkets and wholesale markets. In order to maximize the benefits of the planters, the cooperative contacted a processing plant in Hefei city to try to produce leaf sauce and registered 
a brand of "Quehong" for the sauce. Surprisingly, the sauce was very popular. The committee and the leading group realized that processing is another good avenue to enhance the added value of Chinese toon leaves and to increase the incomes of planters. Moreover, this can stabilize the poor's income because the processing employment could be all year round despite the seasonal characteristic of Chinese toon.

Then, an investment was invited to build a local processing enterprise, further extending the RT industrial chain. With the help of the cooperative and other related organizations, the enterprise gradually explored online and offline sales channels.

"Now, in addition to directly being sold to tourists, 'Quehong' sauce is also being sold on the official website of Hefei Department Store Group Co. Ltd (one of China's top 500 companies), the platform of ULENP (a large e-business platform of agricultural products sponsored by the China Post Group Corporation and Anhui Provincial Government), and in several chain supermarkets. More than 12,000 bottles of sauce have been sold on the online platform just in less than 3 months and all the production of last year would be sold out quickly if the current trend continues."

(Interviewee Z07)

From the above, we can see that there are two important inner linkages for RT, planting, breeding and processing industries. Firstly, despite other separate goals, the development of all industries shares one common goal of increasing the income of the poor. Secondly, the development of all industries has a same fundamental resource-Chinese toon. The common goal and resource integrate the different industries tightly.

\subsubsection{The Integration of Other Stakeholders}

Some non-governmental organizations (NGOs), including a university and various media organizations, were also integrated in the network. The university participated through offering skills training of planting Chinese toon for the planters. A media organization named Anhui Radio was involved through sponsoring publicity activities. To publicize the RT destination and promote its further development, an activity named "the first Chinese toon-picking festival of Zhuanshui Villige" was jointly initiated by the township government and Anhui Radio in April, 2017. The activity theme was "tender leaves picking, folklore performance, agricultural goods procurement and sightseeing tour". The activity also attracted many other media organizations including Xinhuanet, Sina, Netease, Tencent, Sohu, Anhui public channel, Anhui traffic broadcasting, etc., and all these media reported the activity. Due to the publicity, Zhuanshui Village has become a quite famous rural tourism destination, especially in Anhui Province.

"I learned about the destination through the media reports about 'the first Chinese toon-picking festival of Zhuanshui Villige' on the website. I think it is unique and my family come today. We tasted many Chinese toon dishes in a Nongjiale. They were so delicious that we also picked some tender leaves from a local resident's Chinese toon tree and bought them home for my parents and friends."

(Interviewee Z11)

"One day when I was driving I heard the broadcast about 'the first Chinese toon-picking festival of Zhuanshui Villige'. Because my family love eating tender leaves of Chinese toon, we decided to come and have a one-day tour. Of course we also plan to pick tender leaves ourselves from the sightseeing and picking base, and taste Chinese toon dishes in a local Nongjiale."

(Interviewee Z12)

Another media organization named "Anhui Yulan Television Media Co. Ltd." is investing and making a film named "Chinese Toon" in the village. The film is themed on poverty alleviation and based on the story of the village. This is expected to further publicize the fame of the destination. 


\subsection{Embeddedness, Endogeneity and Empowerment of the Integrated Industrial Network}

For a RT network, there are some characteristics for its integration. Despite the separate arguments, the concepts of embeddedness, endogeneity and empowerment are involved in different frameworks $[28,45]$. Thus, we will analyze and examine the established integrated network about its embeddedness, endogeneity and empowerment.

\subsubsection{Embeddedness}

The terminology 'embeddedness' is used to emphasize that rural tourism networks are embedded in particular localities [28,45]. Embeddedness suggested that not only is tourism linked into local resources including the employment base [46], but also relationships are formed within the particular sociocultural contexts [28].

We can find some embeddedness evidence of the RTTAP network in Zhuanshui Village. Firstly, all the industries in the network took local Chinese toon as one kind fundamental resource for their development. RT took it as sightseeing attraction, the planting industry took its tender leaves as final product, the breeding industry took its leaves as unique fodder for livestock and poultry, and the processing industry took its tender leaves as raw material. Secondly, most businesses, including planting enterprises, eco-development enterprises and Nongjiale, were operated by local residents and most of the employees were the local poor. Thirdly, the main type of relationship in the network was informal, soft, and cooperative, also indicating the characteristic of embeddedness. In fact, the relationship with unique sociocultural peculiarities and identities [28] is something like guanxi, a specific Chinese way of life for rural people embedded in their world by establishing and maintaining broad and long-term mutual assistance [33]. For example, the operators of Nongiiale usually passed their diners on to eco-development enterprises through referrals and recommendations. Finally, evidence of embeddedness can also be found in the specific local ways of offering tangible and intangible resources such as locally grown food, accommodation, and "sense of welcome". An example is, most dishes of each Nongjiale included the ingredient of Chinese toon tender leaves.

"There are many enterprises of ecological breeding in the market, how can my enterprise compete with them? Local advantages must be combined in the development. I buy the old leaves from the planters as fodder for the pigs, thus the pork is better than those in the market. Especially, the pigs are named 'Chinese toon pigs'. The same method is used for breeding chook. The demand of my enterprise products exceeds the supply due to the great taste."

(Interviewee Z05)

"I transformed my house into a Nongjiale to cater to the tourists. Most of them come to taste dishes cooked with tender leaves of Chinese toon. There are about 50 diners every day in the picking season, and the total income is about 200,000 Yuan per year."

(Interviewee Z04)

A degree of disembeddedness is also important because it is helpful for linking to external markets, investments and other resources $[28,45]$. In our case, there are three principal means to achieve this. First, through negotiation with the supermarkets and wholesale markets, the products entered surrounding cities. Second, through the online platform, the products entered a nationwide or even worldwide market. The internet was also used for promotion and to access information. Third, in order to acquire external capital, technology and market resources, the village invited the "cosmopolitan local entrepreneur" (a resident who starts a business out of the village) to invest in a processing enterprise, the university to offer skill training, and the media organizations to host activities. However, embeddness and disembeddedness should not be seen as diametrically opposed but rather as interlinked in a dynamic and co-evolving relationship [28]. 


\subsubsection{Endogeneity}

Endogeneity is closely linked to embeddedness, similarly emphasizing a development built around locally distinctive resources [45]. However, endogenous development is structured to retain maximum benefits in a locality by using and adding value to its resources and focusing on the requirements and capacities of its people [28]. The endogeneity evidence of the network are as follows. First, all industries are centered on local Chinese toon and most businesses were privately owned, family-run, and built on the investment of personal savings rather than any grant aid or external investment. Second, strong local participation was encouraged in decision making about village development. There were two main means of local participation. One was communication forums including villagers' committee members, resident representatives and anti-poverty leading group members. Another was individual communications with local elites, "cosmopolitan local entrepreneurs", and the poor.

"We together held 8 communication forums about village development. We also emphasize individual
communications. The local elites and the business operators are able to give some valuable ideas and
suggestions because they are not only familiar with the village but commercially minded. At the same
time, we also need to hear what the poor say. You should give them your heart so that you can hear the
truth. The development plan should take every household into account: the cause for poverty, the labor
conditions, the main difficulty and requirements. We fixed every Monday to visit poor households
until we focused on the theme of Chinese toon."

(Interviewee Z01)

Similarly, endogenous development rarely implies the absence of external exogenous elements. It is a process of continuous negotiation between external and internal elements by local people for a continuous evolution of survival. Exogenous supports from agencies, including Poverty Relief Office of the State Council, Anhui Radio, the county government, the county Agriculture Commission, the county Tourist Administration, organizations like Hangzhou Chamber of Commerce and e-business platforms, have enabled local business operators and residents to easily link their products and activities with outside markets.

\subsubsection{Empowerment}

The final theoretical characteristic of an integrated RT network is empowerment, the aim of which is to enhance the poor's participation $[1,16]$. By making the voice of the poor heard and in full consideration, participation is believed to be able to create larger and balanced economic opportunities for the local poor, contribute to equity and equality, and facilitate sustainable tourism [46,47].

The levels of empowerment are economic, psychological, social and political [48]. In our case, the signs of economic empowerment include: the development of industries in the network has offered diversified income avenues to the local poor, such as payment for employment, rent for transferred land, and payment for Chinese toon tender leaves and other local products. For psychological empowerment, the self-esteem of many poor has been enhanced because of outside recognition of the uniqueness of their village. More importantly, access to income has led to an increase in socioeconomic status for the poor who were traditionally the most disadvantaged [1].

"My family used to be a poor household. In 2015, the yield of the tender leaves reached 1000 kilo, and I sold them to the cooperative at a price of 40 Yuan per kilo. Thus my family had an income of 40,000 Yuan just from the easy planting. In addition, I also work for the sauce-processing enterprise and my wife works for a Nongjiale. And we have paid off all the debts just in two years. Now I feel like I'm being respected."

(Interviewee Z10) 
There are also some other signs of social empowerment. Firstly, village cohesion has been improved as business, individuals and households worked together to attract more tourists. Secondly, some funds raised have been used for village development purposes, for instance to improve infrastructure and public service facilities. Political empowerment provides a platform through which people can raise questions relating to tourism development and have their concerns dealt with [48]. Local participation in communication forums and individual communications in our case have enabled a shared understanding and ownership of objectives. However, this is just the first stage of empowering the poor to make appropriate decisions about their tourism development. In fact, a number of barriers exist for the poor to climb the participation ladder. Most of them are uneducated and usually lack knowledge about decision-making processes which is essential for planning and management. They also have a weak understanding of the tourism system, such as what tourists' needs and wants are, how the industry works, and the variety of development options. All these barriers frequently constrain the poor's active political participation [49].

\subsection{Operating Mechanisms of the Integrated Industrial Network}

Operational mechanisms play key roles in developing the integrated network to innovate RTTAP. In our case, three successive operational mechanisms are highlighted to encourage the participation and collaboration of network stakeholders: vision developing, demonstration driving, and centralized decentralization governance.

\subsubsection{Vision Development}

A vision provides not only a future direction and an overall framework for the mission and goals, but an energizing force for stakeholders communication, participation, and commitment [50]. Obviously, the vision of our case village is to 'become a famous RT destination without poverty'. There are two stages to develop the vision: vision initiation and vision diffusion.

In the first stage, the temporary anti-poverty leader initiated a village vision based on a deep understanding of the village status. He investigated every poor household for the causes of poverty, and frequently held communication forums to analyze and discuss development status and constraints. He also visited local elites and "cosmopolitan local entrepreneurs" for advice to clarify a development idea.

"The causes for every poor household are somehow a little different. The majority are because of the disease, the tuition fee for education, disability or lack of labor. These people have a strong desire to lift themselves out of poverty. We should recognize accurately the main causes of every household to take according measures to help them earn money."

(Interviewee Z01)

"I was born in the village but used to operate my business in Hangzhou City. In March 2014 the leader went to Hangzhou for my advice about the RT development of the village. Honestly I was surprised because I had left for 10 years. He said he found me not only because I have rich business experience, but also I am familiar with both the hometown and the outside market. He hoped I can give some ideas linking local advantages and outside market requirements."

(Interviewee Z07)

Then, in the second stage, the vision was discussed and shared among all villagers, also through communication forums and individual communications. The leader visited every poor household to explain the vision and persuaded them to join the action-planting Chinese toon. Also, during the process of planning and development, the vision was repeatedly stressed to encourage the stakeholders to collaborate. Thus, this stage could be referred to as 'vision diffusion'. 
"In 2014, the leader came to my house and asked some questions about my family. Two months later the village committee called on every household to plant Chinese toon and saplings were freely offered. Of course I followed because I have no other good avenues to earn money. "

(Interviewee Z09)

The vision was smoothly accepted by all the stakeholders. One main reason was the involvement in the vision initiation process through the leader's individual visits or communication forums. Another was the open communication [5,29] and the cognitive trust [51] in the leader based on his intentions, motives, capabilities and predisposition [52].

"I think the leader is trustworthy because he was designated by the provincial government agency and must be knowledgeable. Through the conversation I also felt he really cared about us poor and was helping us poor to earn money. "

(Interviewee Z09)

"I am touched by the leader. After the first time for my advice, he went to Hangzhou another four times to persuade me to invest. He made me believe that it should be a profit-generating business and more meaningful when I go back to my hometown to operate businesses. At last I invested a processing enterprise and a Nongjiale."

(Interviewee Z07)

For the poor, there were other reasons for the acceptance that should not be overlooked. The first was that the poor themselves also had a strong desire to throw off poverty. The second was the relatively low participation cost (free sapling, free planting skill training, and very simple management) and the promised relatively high benefit (an ensured product price).

\subsubsection{Demonstration Driving}

The second operational mechanism to encourage participation is demonstration driving. In the literature on tourism, the concept of 'demonstration effect' commonly refers to local residents' adoption of tourist consumption and spending behaviors $[53,54]$. In this paper, we do not focus on the impact of tourism on locals' behavior in host destinations, but on the impact of some local residents' behavior on others. We found that the preceding planting behavior had a demonstration effect subsequently, even if involved the poor. In fact, in 2015, most of the planters were the poor households because they were eager to increase their incomes, resulting in a still limited planting scale. But in 2016, the planting scale increased sharply because of the obvious economic benefits of poor planters. The remained poor who did not plant, the non-poor, and even the local elites, were all greatly encouraged to participate in the planting action. Thus the term 'demonstration driving' is used to describe this positive demonstration effect.

"Initially most non-poor were reluctant to participate in the planting action because of the low returns in the past. When they saw the benefits of the poor planters, they were all active in planting. Moreover, some local elites were enlightened to introduce greenhouse planting. The planting area is expanding sharply."

(Interviewee Z03)

"In the first year, I just wanted to have a try and was not sure about the benefits, although the leader had promised an ensured price. Most of the planters thought the same as I did, resulting in an initial scattered planting. Excitingly, most of us earned over 20,000 Yuan, an income far beyond expectations. The leader did what he promised. Thus many other people also began to plant in the second year, and now the planting is on a big scale." 
"Those who planted Chinese toon all benefited well. But the traditional planting mode is seasonal, why not plant them in greenhouse? If so, I can sell the products two or three months earlier and at a higher price. To seize the opportunity I went to learn planting skills in greenhouses and raised capital to start a business."

(Interviewee Z06)

\subsubsection{Centralized Decentralization Governance}

The third operational mechanism is centralized decentralization governance. Provan and Kenis [55] have summarized three basic forms of network governance focusing on their distinct structural properties, namely participant-governed network, lead organization-governed network and network administration organization. But the integrated network in the case village is none of these, and it is a centrally led and coordinated but decentralized tourism network. The form of its governance is centralized-decentralization.

'Centralized' refers to the central leadership and coordination of the network by a provincial government department- "The Agency and Staffing Committee Office of Anhui Province” (ASCOAH). ASCOAH is in charge of the designated poverty alleviation work of Anhui Province, thus has sufficient legitimate authority and resources. For the RTTAP development of Zhuanshui Village, it is a regulator, a promoter, and a coordinator [5]. Firstly, the organization appointed a person who can get things done as the temporary anti-poverty leader for Zhuanshui Village, who played a decisive role in the succeeding development. Secondly, the organization coordinated and helped the village to successfully apply for grants from various avenues. Total grants have reached 20 million yuan (nearly 3.126 million dollars) and all of them have been used for infrastructure construction, public service facilities, and RT industry development projects. Thirdly, the organization helped the village to build relationships with outsiders, including the university, Anhui Radio, etc., to involve them in the development.

'Decentralization' refers to the self-governance of the network. Although ASCOAH played a key role in leadership and coordination, the villagers' committee and village anti-poverty leading group were responsible for the development of RTTAP, and the operators were responsible for managing their own businesses. Firstly, the committee and leading group needed to make an overall plan, take action and integrate all the stakeholders for the achievement of the network-level goal. Unlike the traditional, ineffective and unsustainable charity-based approach in poverty alleviation [56], they aimed to help the poor to build the income-generation capacity [57]. They actively applied for grants. With the grants, they developed a tour and sightseeing base; paved and widened the road to improve tourism transportation; built new sewage-treatment station, a public lavatory, and parking lots to offer tourists good public services. They also wisely applied for the organic product certification and registered the brand. All these decisions and measures reached out to all stakeholders of the network and integrated them effectively. "It's much better to provide conditions and teach us poor how to earn money than directly give us money" (Interviewee Z09). Secondly, the operators needed to decide the business field, develop their own products to attract tourists or customers, and manage daily business.

\subsection{Sustainability of the RTTAP Development}

Sustainability highlights the need to view RTTAP development from a long-term perspective. Besides some basic principles of a sustainable tourism development mentioned earlier, including local economic growth enhancement, poverty reduction, and self-esteem gaining of local poor [58], we further discuss another three sustainability related problems of RTTAP development. In fact, the problems are also possible challenges for RTTAP development.

The first is whether the established competitive advantages have the potential to be persistent. Without prominent tourism resource endowment, Zhuanshui Village innovated network construction to seek competitive advantages. It explored deeply and wisely deployed the limited featured resource of Chinese toon to develop related industries. Obviously, through the linkage development of multiple industries based on Chinese toon, the integrated network has offered various income avenues for 
the poor and makes their income more stable compared to merely a single income source. There is little doubt that the income stability could help prevent the poor from returning to poverty. But at the same time, the possible unsustainability should not be neglected due to the replicability of the village attractiveness, despite its currently increasing tourists and good development momentum. Chinese toon is widely distributed in central and southern China, thus all the industries of the village, including the planting, breeding, processing, and tourism, could be developed in any rural areas where Chinese toon could survive. In order to achieve sustainable development, inter-regional cooperation [1] is a potential strategy for the village. On the one hand, drawing on the strength of the established brand of "Quehong" and growing fame, Zhuanshui Village could coordinate the development of Chinese toon in surrounding villages to form a cross-village and more influential base. On the other hand, the village could make efforts to become one of the important destinations of the existing attraction cluster nearby which includes several national scenic spots.

The second is the structure of public administration which is always regarded as a challenge of sustainable tourism development in the developing world [58]. As analyzed in 4.3, the network governance structure is a centralized-decentralization one, and the leader for anti-poverty is designated by ASCOAH. Thus the leader is always temporary. To our knowledge, ASCOAH will appointed another person to be the new anti-poverty leader of the village and the current one will be back to his original provincial government department. However, the positive effects of the structure, an impermanent leader for anti-poverty, is unfavourable for sustainability because the leader usually is the most important strategic decision maker. Thus, there is a need to encourage a capable person to be a relatively stable leader for RTTAP.

The third is potential environmental degradation. With the growing number of tourists, the rural tourism resources would bear an increasing pressure without a scientific and rational management policy in place [3]. This should be especially emphasized for impoverished destinations, because there is an overlap between unsustainably environmental actions and poverty [59]. In order to protect the environment, the village should make policies and decisions for further development from a future-oriented vision instead of a money driven mind-set [1]. At the same time, the village also should take measures to cope with waste. For example, it could implement strict control and regulation to prevent the generation of new or increased waste residues; and the installation of sewage-disposal systems should take into account both the local residents' needs and tourism development.

\section{Conclusions}

When linking rural tourism with poverty alleviation, an impoverished area may be confronted with two challenges: how to develop with a very limited tourism resource endowment and how to target the poor as the main beneficiaries. This paper has explored how the case village successfully met the challenges through an integration of tourism with its extension industries. The integrated network offered more income avenues for the poor and effectively alleviated poverty. This paper focuses on the development process, characteristics and operation mechanisms of the integrated network.

As an impoverished destination, Zhuanshui Village almost had no comparative advantages, thus it turned to building competitive advantages [60]. Aiming at the central objective of poverty alleviation, it sought competitive advantages by deep exploration and wise deployment of the limited featured resource in hand-traditional Chinese toon. The development of RT and its extensions to planting, breeding, processing industries were all embedded in local features and took local Chinese toon as one kind fundamental resource. Because of the common objective and the same fundamental resource, the different industries were integrated tightly. RT was also tactfully combined with other related industries to alleviate poverty together.

The acknowledged characteristics of an integrated RT network, named embeddedness, endogeneity and empowerment, are analyzed and examined for the established multi-industries integration network of the village. Disembeddedness and exogeneity are also analyzed. Enough evidence has been found for each characteristic. However, embeddness and disembeddedness, 
endogeneity and exogeneity, should not be seen as diametrically opposed but rather as interlinked in a dynamic and co-evolving relationship. Despite the existence of economic, psychological, social and political empowerment, the poor's participation is just the first stage to make appropriate decisions about the development due to their inadequate capabilities.

Three operational mechanisms are vital to encourage the participation and collaboration of stakeholders in the development of the integrated network. The first is vision developing. The temporary anti-poverty leader initiated a vision (vision initiation) and then, the vision was discussed and shared among all villagers (vision diffusion). Both the vision initiation and vision diffusion were by means of communication forums and individual communications. The second is demonstration driving. We found that the preceding planting behavior had a demonstration effect on the others. Although most of the preceding planters were poor, the exciting benefits encouraged the remaining poor, the non-poor, and even the local elites to follow, promoting a sharp increase of planting area. The third is centralized decentralization governance. In China, due to the scarcity of resources and the absence of a strong and experienced private sector, government tends to take an active role in the development and operation of tourism [5]. Similarly, the integrated network was centrally led and coordinated by ASCOAH. But at the same time, the development of RTTAP was in charge of the villagers' committee and village anti-poverty leading group, and thus it was also self-governance.

Three sustainability related problems of the RTTAP development are also discussed. The first is the sustainability of the established competitive advantages. The replicability of the village's attractiveness cannot be neglected despite its good development momentum, and establishing interregional partnerships could be a potential solution. The second is the temporality of the major leader caused by the current public administration structure. In order to enhance the sustainability of RTTAP, there is a need of a relatively stable leader. The third is the potential environmental degradation. The village should make policy and decisions from a long-term, future-oriented vision as well as take measures to cope with the waste. In fact, these problems are also possible challenges.

The case offered by this paper takes a combination of RT and its extension industries as a valuable approach to target poverty alleviation. Considering that the appropriateness of a certain development approach is highly dependent upon specific circumstances [1], and RTTAP research is essentially oriented to solving the poverty problem, more empirical research in the search for an optimum combination is strongly suggested to contribute to theoretical development.

Author Contributions: N.F. conceived the research, and undertook the main work; F.W. collected media reports, participated in the interviews and collated the data. During the progress of design and implementation, K.H.Z. provided some guiding suggestions; X.G. participated in the revision of the manuscript.

Acknowledgments: This work was supported by the National Natural Science Foundation of China under Grant number 71303073, 71571060, 71690230, 71601066, 71671057, 71501055, Key Projects of Philosophy and Social Sciences in Anhui under Grant number AHSKZ2015D17.

Conflicts of Interest: The authors declare no conflict of interest.

\section{References}

1. Zhao, W.; Ritchie, J.R.B. Tourism and poverty alleviation: An integrative research framework. Curr. Issues Tour. 2007, 10, 119-143. [CrossRef]

2. Blake, A.; Arbache, J.S.; Sinclair, M.T.; Teles, V. Tourism and poverty relief. Ann. Tour. Res. 2008, 35, $107-126$. [CrossRef]

3. Wang, L.-E.; Cheng, S.-K.; Zhong, L.-S.; Mu, S.-L.; Dhruba, B.G.C.; Ren, G.-Z. Rural tourism development in China: Principles, models and the future. J. Mt. Sci. 2013, 10, 116-129. [CrossRef]

4. Gao, J.; Wu, B. Revitalizing traditional villages through rural tourism: A case study of Yuanjia Village, Shaanxi Province, China. Tour. Manag. 2017, 63, 223-233. [CrossRef]

5. Ying, T.; Zhou, Y. Community, governments and external capitals in China's rural cultural tourism: A comparative study of two adjacent villages. Tour. Manag. 2007, 28, 96-107. [CrossRef] 
6. Truong, V.D.; Hall, C.M.; Garry, T. Tourism and poverty alleviation: Perceptions and experiences of poor people in Sapa, Vietnam. J. Sustain. Tour. 2014, 22, 1071-1089. [CrossRef]

7. Pinho, S.N.J.C. Stakeholder network integrated analysis the specific case of rural tourism in the Portuguese Peneda-Gerês national park. Int. J. Tour. Res. 2015, 17, 325-336.

8. Bennett, O.; Roe, D.; Ashley, C. Sustainable Tourism and Poverty Elimination: A Report for the Department for International Development; Deloitte and Touche: London, UK; IIED: London, UK; ODI: London, UK, 1999.

9. Ashley, C.; Roe, D.; Goodwin, H. Pro-Poor Tourism Strategies: Making Tourism Work for the Poor-A Review of Experience 2001. Available online: https:/ /www.odi.org/sites/odi.org.uk/files/odi-assets / publications-opinion-files/3246.pdf (accessed on 24 June 2018).

10. Snyman, S.L. The role of tourism employment in poverty reduction and community perceptions of conservation and tourism in southern Africa. J. Sustain. Tour. 2012, 20, 395-416. [CrossRef]

11. Mitchell, J. Value chain approaches to assessing the impact of tourism on low-income households in developing countries. J. Sustain. Tour. 2012, 20, 457-475. [CrossRef]

12. Erskine, L.M.; Meyer, D. Influenced and influential: The role of tour operators and development organisations in tourism and poverty reduction in Equador. J. Sustain. Tour. 2012, 20, 339-357. [CrossRef]

13. Goodwin, H. Reflection on 10 years of pro-poor tourism. J. Policy Res. Tour. Leisure Events 2009, 1, 90-94. [CrossRef]

14. Koens, K.; Thomas, R. "You know that's a rip-off": Policies and practices surrounding micro-enterprises and poverty alleviation in South African township tourism. J. Sustain. Tour. 2016, 24, 1641-1654. [CrossRef]

15. Manyara, G.; Jones, E. Community-based Tourism Enterprises Development in Kenya: An Exploration of Their Potential as Avenues of Poverty Reduction. J. Sustain. Tour. 2007, 15, 628-644. [CrossRef]

16. Scheyvens, R.; Russell, M. Tourism and poverty alleviation in Fiji: Comparing the impacts of small- and large-scale tourism enterprises. J. Sustain. Tour. 2012, 20, 417-436. [CrossRef]

17. Tucker, H.; Boonabaana, B. A critical analysis of tourism, gender and poverty reduction. J. Sustain. Tour. 2012, 20, 437-455. [CrossRef]

18. Davidson, L.; Sahli, M. Foreign direct investment in tourism, poverty alleviation, and sustainable development: A review of the Gambian hotel sector. J. Sustain. Tour. 2014, 23, 167-187. [CrossRef]

19. Rogerson, C.M. Tourism-agriculture linkages in rural South Africa: Evidence from the accommodation sector. J. Sustain. Tour. 2012, 20, 477-495. [CrossRef]

20. Hummel, J.; van der Duim, R. Tourism and development at work: 15 years of tourism and poverty reduction within the SNV Netherlands Development Organisation. J. Sustain. Tour. 2012, 20, 319-338. [CrossRef]

21. Saxena, G.; Ilbery, B. Integrated rural tourism a border case study. Ann. Tour. Res. 2008, 35, $233-254$. [CrossRef]

22. Lane, B. What is rural tourism? J. Sustain. Tour. 1994, 2, 7-21. [CrossRef]

23. Sharpley, R.; Roberts, L. Rural tourism-10 years on. Int. J. Tour. Res. 2004, 6, 119-124. [CrossRef]

24. Su, B. Rural tourism in China. Tour. Manag. 2011, 32, 1438-1441. [CrossRef]

25. Romeiro, P.; Costa, C. The potential of management networks in the innovation and competitiveness of rural tourism: A case study on theValle del Jerte (Spain). Curr. Issues Tour. 2010, 13, 75-91. [CrossRef]

26. Iorio, M.; Corsale, A. Community-based tourism and networking: Viscri, Romania. J. Sustain. Tour. 2013, 22, 234-255. [CrossRef]

27. Tolstad, H.K. Development of rural-tourism experiences through networking: An example from Gudbrandsdalen, Norway. Nor. Geogr. Tidsskr. Nor. J. Geogr. 2014, 68, 111-120. [CrossRef]

28. Kelliher, F.; Reinl, L.; Johnson, T.G.; Joppe, M. The role of trust in building rural tourism micro firm network engagement: A multi-case study. Tour. Manag. 2018, 68, 1-12. [CrossRef]

29. Park, D.-B.; Lee, K.-W.; Choi, H.-S.; Yoon, Y. Factors influencing social capital in rural tourism communities in South Korea. Tour. Manag. 2012, 33, 1511-1520. [CrossRef]

30. Bock, I.A.D.A.; Macke, J. The social capital and the development of collaborative networks in the tourism sector a case study on the grupo gestor do tourism rural do. Rev. Bras. Pesqui. Tur. 2014, 8, 23.

31. Panyik, E.; Costa, C.; Rátz, T. Implementing integrated rural tourism: An event-based approach. Tour. Manag. 2011, 32, 1352-1363. [CrossRef]

32. Chen, X. A phenomenological explication of Guanxi in rural tourism management: A case study of a village in China. Tour. Manag. 2017, 63, 383-394. [CrossRef] 
33. Komppula, R. The role of individual entrepreneurs in the development of competitiveness for a rural tourism destination-A case study. Tour. Manag. 2014, 40, 361-371. [CrossRef]

34. Mak, B.; Cheung, L.; Hui, D. Community participation in the decision-making process for sustainable tourism development in Rural Areas of Hong Kong, China. Sustainability 2017, 9, 1695. [CrossRef]

35. Liu, S.; Cheng, I.; Cheung, L. The roles of formal and informal institutions in small tourism business development in Rural Areas of South China. Sustainability 2017, 9, 1194. [CrossRef]

36. Haven-Tang, C.; Jones, E. Local leadership for rural tourism development: A case study of Adventa, Monmouthshire, UK. Tour. Manag. Perspect. 2012, 4, 28-35. [CrossRef]

37. Li, P.; Ryan, C.; Cave, J. Chinese rural tourism development: Transition in the case of Qiyunshan, Anhui.-2008-2015. Tour. Manag. 2016, 55, 240-260. [CrossRef]

38. Hwang, J.; Lee, S. The effect of the rural tourism policy on non-farm income in South Korea. Tour. Manag. 2015, 46, 501-513. [CrossRef]

39. Lin, D.; Simmons, D. Structured inter-network collaboration: Public participation in tourism planning in Southern China. Tour. Manag. 2017, 63, 315-328. [CrossRef]

40. Xue, L.; Kerstetter, D.; Hunt, C. Tourism development and changing rural identity in China. Ann. Tour. Res. 2017, 66, 170-182. [CrossRef]

41. Cawley, M.; Gillmor, D.A. Integrated rural tourism:concepts and practice. Ann. Tour. Res. 2008, 35, 316-337. [CrossRef]

42. Eisenhardt, K.M. Building theories from case study research. Acad. Manag. Rev. 1989, 14, 532-550. [CrossRef]

43. Yin, R.K. Case Study Research: Design and Methods, 2nd ed.; Sage: Newbury Park, CA, USA, 1994.

44. Eisenhardt, K.M.; Graebner, M.E. Theory building from cases: Opportunities and challenges. Acad. Manag. J. 2007, 50, 25-32. [CrossRef]

45. Scheyvens, R. Ecotourism and the empowerment of local communities. Tour. Manag. 1999, 20, $245-249$. [CrossRef]

46. Tosun, C. Stages in the emergence of a participatory tourism development approach in the developing world. Geoforum 2005, 36, 333-352. [CrossRef]

47. Keogh, B. Public participation in community tourism planning. Ann. Tour. Res. 1990, 17, 449-465. [CrossRef]

48. Kalantaridis, C.; Bifka, Z. Local Embeddedness and Rural Entrepreneurship: Case-Study Evidence from Cumbria, England. Environ. Plan. A 2006, 38, 1561-1579. [CrossRef]

49. Cole, S. Information and Empowerment: The Keys to Achieving Sustainable Tourism. J. Sustain. Tour. 2011, 14, 629-644. [CrossRef]

50. Morris, E. Stategy and vision: A focus for the future. J. Bus. Strategy 1987, 8, 51-58. [CrossRef]

51. McAllister, D.J. Affect and cognition-based trust as foundations for interpersonal cooperation in organizations. Acad. Manag. J. 1995, 38, 24-59.

52. Czernek, K.; Czakon, W. Trust-building processes in tourist coopetition: The case of a Polish region. Tour. Manag. 2016, 52, 380-394. [CrossRef]

53. Monterrubio, J.C.; Mendoza-Ontiveros, M.M. Tourism and the demonstration effect: Empirical evidence. Tour. Manag. Stud. 2014, 10, 97-103.

54. David, F. The demonstration effect revisited. Ann. Tour. Res. 2004, 31, 428-446.

55. Provan, K.G.; Kenis, P. Modes of network governance: Structure, management, and effectiveness. J. Public Adm. Res. Theory 2007, 18, 229-252. [CrossRef]

56. World Bank. Assessing Aid: What Works, What doesn't, and Why; World Bank Policy Research Report; Oxford University Press: New York, NY, USA, 1998.

57. United Nations Industrial Development Organization (UNIDO). Building Productive Capacity for Poverty Alleviation in Least Developed Countries (LDC's): The Role of Industry; UNIDO: Vienna, Austria, 2001.

58. Tosun, C. Challenges of sustainable tourism development in the developing world: The case of Turkey. Tour. Manag. 2001, 22, 289-303. [CrossRef] 
59. Dasgupta, S.; Deichmann, U.; Meisner, C.; Wheeler, D. Where is the poverty-environment nexus? Evidence from Cambodia, Lao PDR, and Vietnam. World Dev. 2005, 33, 617-638. [CrossRef]

60. Ritchie, J.R.B.; Crouch, G.I. The competitive destination: A sustainability perspective. Tour. Manag. 2000, 21, $1-7$. article distributed under the terms and conditions of the Creative Commons Attribution (CC BY) license (http:/ / creativecommons.org/licenses/by/4.0/). 